\title{
PENDIDIK KARAKTER YANG MEMOTIVASI DAN MENGINSPIRASI
}

\author{
Simon M. Tampubolon \\ Character Building Development Center, BINUS University \\ Jln. Kemanggisan Ilir III No. 45, Kemanggisan - Palmerah, Jakarta 11480 \\ simon@binus.ac.id
}

\begin{abstract}
Article discusses how character educators in universities meet the challenges of character education in college. This article describes how the character educators in college should be educators who motivate and inspire. It is as a response to the challenges that the characters have already been formed in the students themselves. Article describes contemplation, principles, and patterns to be the educators of character who motivate and inspire character.
\end{abstract}

Keywords: educators, character, motivation

\begin{abstract}
ABSTRAK
Artikel membahas bagaimana para pendidik karakter di lingkungan perguruan tinggi menjawab tantangan pendidikan karakter di perguruan tinggi. Artikel ini menjelaskan bagaimana para pendidik karakter di perguruan tinggi harus menjadi pendidik yang memotivasi dan menginspirasi. Hal itu sebagai jawaban atas tantangan karakter yang sudah terbentuk pada diri mahasiwa. Artikel menjelaskan perenungan, prinsip, dan pola menjadi pendidik karakter yang memotivasi dan menginspirasi.
\end{abstract}

Kata kunci: pendidik, karakter, motivasi 


\section{PENDAHULUAN}

Undang-undang tentang sistem pendidikan nasional pasal 1 ayat 1 dan 2 menyatakan: (1) Pendidikan adalah usaha sadar dan terencana untuk mewujudkan suasana belajar dan proses pembelajaran agar peserta didik secara aktif mengembangkan potensi dirinya untuk memiliki kekuatan spiritual keagamaan, pengendalian diri, kepribadian, kecerdasan, akhlak mulia, serta keterampilan yang diperlukan dirinya, masyarakat, bangsa dan negara; (2) Pendidikan nasional adalah pendidikan yang berdasarkan Pancasila dan Undang-Undang Dasar Negara Republik Indonesia Tahun1945 yang berakar pada nilai-nilai agama, kebudayaan nasional Indonesia dan tanggap terhadap tuntutan perubahan zaman. Selanjutnya pasal 2 ayat 3 berbunyi: Pendidikan nasional berfungsi mengembangkan kemampuan dan membentuk watak serta peradaban bangsa yang bermartabat dalam rangka mencerdaskan kehidupan bangsa, bertujuan untuk berkembangnya potensi peserta didik agar menjadi manusia yang beriman dan bertakwa kepada Tuhan Yang Maha Esa, berakhlak mulia, sehat, berilmu, cakap, kreatif, mandiri, dan menjadi warga negara yang demokratis serta bertanggung jawab.

Pasal-pasal tersebut menegaskan bahwa pendidikan adalah usaha sadar dan terencana untuk mewujudkan suasana belajar dan pembelajaran yang mengaktifkan siswa dan mengembangkan potensi diri siswa dalam aspek spiritual keagamaan, pengendalian diri, kepribadian, kecerdasan, akhlak mulia, dan keterampilan. Sementara Undang-Undang No. 12 tahun 2012 pasal 4 tentang tujuan pendidikan tinggi mengatakan tujuan pendidikan tinggi adalah (a) mengembangkan potensi mahasiswa agar menjadi manusia yang beriman dan bertakwa kepada Tuhan Yang Maha Esa dan berakhlak mulia; (b) menghasilkan lulusan yang menguasai bidang ilmu, teknologi, dan/atau seni yang dipelajari serta mampu mengaplikasikan dalam peningkatan daya saing bangsa serta memiliki sikap toleran, demokratis, berkarakter tangguh, serta berani membela kebenaran untuk kepentingan nasional; dan (c) menghasilkan karya penelitian dalam bidang ilmu, teknologi, dan/atau seni yang bermanfaat bagi kemaslahatan bangsa, negara, dan umat manusia.

Menyimak undang-undang tersebut, terlihat jelas karakter-karakter yang diletakkan sebagai tujuan dari pendidikan tersebut yaitu beriman, bertakwa, berakhlak mulia, toleran, demokratis, tangguh dan berani membela kebenaran. Pada rancangan kebijakan nasional pembangunan karakter bangsa 2010-2025 ditegaskan bahwa Lingkup Satuan Pendidikan mulai dari usia dini sampai dengan perguruan tinggi merupakan salah satu lingkup dari pendidikan karakter bangsa di samping lingkup keluarga dan pemerintah. Kebijakan nasional tersebut berbunyi:

Satuan pendidikan merupakan wahana pembinaan dan pengembangan karakter yang dilakukan dengan menggunakan (a) pendekatan terintegrasi dalam semua mata pelajaran, (b) pengembangan budaya satuan pendidikan, (c) pelaksanaan kegiatan kokurikuler dan ekstrakurikuler, serta (d) pembiasaan perilaku dalam kehidupan di lingkungan satuan pendidikan. Pembangunan karakter melalui satuan pendidikan dilakukan mulai dari pendidikan usia dini sampai pendidikan tinggi. (Dokumen Kebijakan Nasional Pembangunan Karakter Bangsa 2010-2025:5)

Rincian atas lingkup pendidikan ini juga menjelaskan tahap-tahap pendidikan karakter mulai dari pendekatan, pengembangan dan akhirnya pembiasaan atas karakter-karakter yang ditanamkan mulai dari pendidikan anak usia dini (PAUD) sampai dengan pendidikan tinggi (PT).

Pada pendidikan usia dini penanaman karakter memang harus menjadi hal yang utama karena sekitar 70\% pembentukan karakter manusia dimulai dari usia nol hingga tiga tahun (PDPERSI, 2012). Hasil penelitian Mulyatiningsih (n.d.) menunjukkan sekitar 50\% variabilitas kecerdasan orang dewasa sudah terjadi ketika anak berusia empat tahun. Peningkatan 30\% berikutnya terjadi pada usia delapan tahun, dan 20\% sisanya pada pertengahan atau akhir dasawarsa kedua. Lebih jauh dikatakan, pendidikan karakter pada usia dini di keluarga bertujuan untuk pembentukan; pada usia remaja di 
sekolah bertujuan untuk pengembangan. Sedangkan pada usia dewasa di bangku kuliah bertujuan untuk pemantapan. Tugas-tugas pendidik adalah menyediakan lingkungan belajar yang baik untuk membentuk, mengembangkan, dan memantapkan karakter peserta didiknya.

Melihat adanya usia emas dalam pendidikan karakter tersebut, maka pada pendidikan tinggi tampaknya pendidikan karakter tidak lagi berpengaruh besar pada pembentukan karakter, tetapi hanya berperan pada pemantapan. Hasil penelitian Fahtudin dalam Mulyatiningsih (n.d.) yang dilaksanakan dengan metode kuasi eksperimen menunjukkan tidak ada perbedaan antara kelompok eksperimen yang menggunakan model penilaian self and peer assessment dengan kelompok kontrol yang menggunakan penilaian paper and pencil test dalam ketaatan beribadah harian sesuai dengan tuntunan agama Islam. Laporan penelitian menyarankan bahwa untuk membentuk kultur akhlak mulia mahasiswa diperlukan waktu yang panjang melalui pembiasaan-pembiasaan. Karakter pada orang dewasa seperti mahasiswa memang sudah memfosil atau sulit diubah melalui strategi pembelajaran biasa.

Asyanti (2012) menjelaskan lebih jauh bahwa yang menyebabkan pendidikan karakter di perguruan tinggi akan menemui kendala karena adanya pendapat keliru, yaitu: (1) karakter seseorang sudah terbentuk sebelum masuk ke perguruan tinggi dan merupakan tanggung jawab orangtua untuk membentuk karakter anaknya; (2) perguruan tinggi, khususnya dosen, tidak memiliki kepentingan dengan pembentukan karakter, karena mereka direkrut bukan untuk melakukan hal tersebut; (3) karakter merupakan istilah yang mengacu pada agama atau ideologi konservatif tertentu, sementara itu perguruan tinggi di barat secara umum melepaskan diri dari agama atau ideologi tertentu.

Usia emas bagi pembentukan anak, hasil penelitian yang ada dalam pendidikan karakter bagi orang dewasa, dan pendapat yang keliru yang ada menjadi hal yang harus dipikirkan lebih mendalam lagi agar pendidikan karakter di pendidikan tinggi bukan sekadar pemantapan mealinkan mampu menginspirasi, sehingga para peserta didik di perguruan tinggi dapat mengalami penguatan dan pembentukan karakter. Kunci dari pelaksanaannya ada pada para pendidik karakter itu sendiri. Dikatakan, karakter mahasiswa sulit diubah jika hanya melalui strategi pembelajaran biasa. Hal itu memerlukan strategi pembelajaran yang luar biasa untuk memecah fosil karakter yang sudah mengeras dan membentuk kembali menjadi sesuatu yang baru. Selain itu, dibutuhkan pendidik yang luar biasa juga; seorang pendidik yang peduli dengan perkembangan karakter, pendidik yang memotivasi, dan menginspirasi. Tema pendidikan karakter yang memotivasi dan menginspirasi ini akan dibahas pada artikel ini, dengan satu keyakinan bahwa keberadaan pendidik yang memotivasi dan menginspirasi adalah salah satu jawaban kunci atas tantangan pendidikan karakter di perguruan tinggi.

\section{METODE}

Penelitian untuk penulisan artikel ini menggunakan metode penelitian kepustakaan (library research). Studi kepustakaan yang dilakukan menggunakan sumber bacaan yang relevan dan tersedia sesuai dengan topik yang hendak dikaji dan dikembangkan. Sumber pustaka yang tersedia tersebut dijadikan bahan untuk memahami dan mengembangkan berbagai aspek penting yang menjadi pembahasan dalam tulisan ini.

\section{HASIL DAN PEMBAHASAN}

Beberapa penjelasan pada pendahuluan menunjukkan pendidikan karakter di perguruan tinggi hanyalah bersifat pemantapan ataupun pengasahan karena karakter peserta didik sudah terbentuk. Mulyatiningsih (n.d.) dalam penelitiannya menjelaskan karakter pada orang dewasa sudah terbentuk 
sejak anak-anak dan remaja. Pendidikan karakter untuk mahasiswa atau orang dewasa melalui model-model pembelajaran belum tentu efektif dilaksanakan. Pendidikan karakter orang dewasa yang sesuai seharusnya melalui peningkatan kesadaran untuk berperilaku positif dan evaluasi diri (self evaluation). Pendidikan karakter lebih efektif jika muncul dari kesadaran diri sendiri, bukan pengaruh dari orang lain. Bentuk-bentuk pendidikan karakter antara lain dilakukan melalui ceramah dan pengajian, pengangkatan tema pendidikan karakter dalam forum seminar, diskusi, media massa, film, penulisan karya ilmiah yang bertema pendidikan karakter, belajar dari pengalaman hidup orang lain, dsb. Banyak pengalaman orang-orang yang berkarakter negatif dapat berubah menjadi positif setelah mereka dihadapkan pada permasalahan hidup dan belajar dari kehidupan orang lain yang sedang mengalami masalah.

Dengan demikian, pendidikan karakter pada perguruan tinggi harus memiliki daya dobrak yang luar biasa; harus menjadi sebuah proses yang menginspirasi pembaharuan; harus menjadi sebuah proses yang mengubah paradigma atau membawa mahasiswa pada suatu titik balik atau pencerahan. Pendidikan karakter bagi para mahasiswa di perguruan tinggi harus merupakan proses memberi motivasi, untuk menghasilkan perubahan dari dalam ke luar pada diri mahasiswa.

Para mahasiwa membutuhkan motivasi untuk mengarahkan diri mereka, mempertajam karakter mereka dan juga membarui diri mereka dengan etika karakter yang baik, sehingga mereka boleh berhasil dalam studi dan kehidupan mereka. Sebelum lebih jauh, perlu diingat Steven Covey, Zig Ziglar, Mario Teguh, Tung Desem Waringin, Ary Ginanjar Agustian, dan para motivator lainnya, sebagian besar berceramah dan memberi motivasi bagi orang-orang yang sudah dewasa. Hal ini mengingatkan bahwa secara praktis perubahan motif, karakter, dan paradigma masih dimungkinkan pada usia berapa pun. Pada dasarnya para motivator ingin membangkitkan suatu hal yang disebut Covey (1997) etika kepribadian. Etika kepribadian adalah suatu fungsi kepribadian, citra, sikap dan perilaku, keterampilan dan teknik untuk melicinkan proses interaksi dengan orang lain (Covey, 1997). Covey (1997) menawarkan sesuatu yang disebut etika karakter untuk menggapai sebuah keberhasilan. Dengan demikian salah satu hal utama yang dibutuhkan adalah sosok pribadi yang mampu mentransferkan semangat perubahan itu. Begitu pula dalam pendidikan karakter di perguruan tinggi bagi para mahasiswa. Mahasiswa membutuhkan sosok pribadi pendidik yang memotivasi dan memberi inspirasi serta mentransferkan semangat perubahan pada diri mereka.

Sosok pendidik yang memotivasi atau yang "Ing Madya Mangun Karsa” sangat dibutuhkan dalam pembentukan karakter bagi para mahasiswa. Mahasiswa butuh teladan dan motivasi yang membuat mereka bisa memaknai diri mereka dalam konteks studi yang bertanggung jawab, kehidupan sosial yang dinamis, dan dalam konteks meraih cita-cita bagi kemanusiaan. Di sinilah para pendidik seharusnya menjadi motivator.

\section{Perenungan Pendidik yang Memotivasi}

Para pendidik di perguruan tinggi (dosen) hanya dapat menjadi seorang motivator jika mereka pertama-tama merenungkan apa yang ada di pusat kehidupan mereka. Covey (1997:99) mengatakan: "Apapun yang ada di pusat kehidupan kita, akan menjadi sumber dari rasa aman, pedoman, kebijaksanaan dan daya kita.” Jika di pusat kehidupannya pendidik menaruhkan hal-hal yang bersifat lahiriah semata, motivasi-motivasi yang diberikan pun hanyalah sebatas hal-hal lahiriah. Namun jika seorang pendidik menaruh prinsip panggilan dan pengabdian pada pusat kehidupannya, motivasi yang muncul secara alamiah dalam dirinya akan membawa pengaruh bagi mahasiswanya.

Rasa aman para pendidik yang berpusat pada prinsip panggilan dan pengabdian terletak pada panggilan dan pengabdiannya sebagai pendidik. Ia aman jika ia mampu menjalankan tugas dan panggilannya sebagai pendidik yang membawa perubahan dalam diri mahasiswanya. Kebijaksanaan dan pedoman para pendidik yang berpusat pada prinsip berasal dari satu wawasan yang benar dan 
tepat tentang panggilan dan pengabdiannya. Dengan begitu, ia dapat mengambil keputusan dengan menggunakan data yang benar dan membuat keputusan itu memungkinkan dan bermakna.

Sementara daya pendidik yang berpusat pada prinsip panggilan dan pengabdian adalah daya alamiah yang muncul dari kesadaran diri, pengetahuan yang luas, individu yang proaktif dan tidak dibatasi oleh sikap, perilaku dan tindakan para mahasiswanya atau oleh keadaan dan keadaan lingkungan yang sering kali membatasi.

Perenungan kedua bagi para pendidik yang memotivasi adalah merenungkan hubungan dengan para mahasiswa. Para pendidik harus melihat kembali, selama ini siapakah para mahasiswa itu di matanya. Hal ini berarti para pendidik harus merefleksikan kembali relasi yang mereka bangun dengan para mahasiswa. Martin Burber (dalam Snijders, 2004) membedakan tiga jenis relasi antara manusia, yaitu relasi "aku-itu”, "aku-dia” dan "aku-engkau”, yang merupakan pola relasi yang biasa terjadi dalam interaksi manusia.

Dalam relasi "aku-itu” pendidik memandang mahasiswa hanya sebagai objek dari pengajaran yang hanya perlu dicekoki materi pelajaran. Sejauh mahasiswa membawa keuntungan, maka ia akan diperlakukan dengan baik, namun jika tidak, "ya sudah, tidak perlu repot-repot." Mahasiswa dalam hubungan ini tidak dipandang sebagai pribadi yang unik-otonom, mereka hanyalah sebuah objek. Jenis relasi ini terjadi dalam sikap pragmatis.

Dalam relasi "aku-dia” mahasiswa dipandang sebagai subjek yang netral. Pendidik dalam relasi ini akan bersikap acuh terhadap mahasiswa karena ia berpikir bahwa ia tidak bertanggung jawab atas kebahagiaan dan pertumbuhan orang lain. Hubungan yang ada hanya sejauh para mahasiswa berfungsi di mata para pendidik, sehingga percakapan yang dibangun hanyalah sebuah basa-basi yang tidak penting. Hubungan di sini seperti hubungan antara pelanggan restoran dengan pelayan. Pendidik tidak berminat lebih jauh melihat perkembangan mahasiswa, yang penting siswa sudah berfungsi sewajarnya, dan itu sudah cukup.

Relasi yang memotivasi dan menginspirasi adalah relasi "aku-engkau". Para pendidik dan siswa adalah makhluk sosial yang merindukan suatu kesatuan dan kebersamaan yang semakin lama dan semakin mendalam. Dalam relasi ini kasih berbicara. Pertumbuhan dan perkembangan orang lain menjadi suatu panggilan penting yang harus diwujudkan dalam suatu pengabdian. Dalam relasi ini siswa dipandang sebagai subjek, siswa dan pengajar saling mendukung dan memberi. Dalam relasi ini keuntungan bukanlah tujuan, basa-basi tidaklah penting, sikap acuh bukanlah cara yang benar, namun yang ada adalah hubungan yang mencipta. Suatu hubungan kreatif yang membuat semua pihak saling berada. Tentunya motivasi adalah bahasa yang akan terus keluar dan memberikan dampak yang kokoh.

Untuk menjadi subjek pendidik yang memotivasi, para pendidik karakter harus merenungkan kembali ekspektasi terhadap para mahasiswanya selama ini. Wong (2009) menjelaskan bahwa pendidik yang efektif adalah pendidik yang memiliki ekspektasi positif, yaitu sebuah keyakinan yang optimistis bahwa siapa pun yang diajar atau apa pun yang dilakukan akan menghasilkan kesuksesan. Hal ini bisa terjadi karena ketika ekspektasi positif itu bekerja, Anda akan mengalokasikan banyak energi untuk meraih peluang apa pun yang ada.

Wong (2009) menjelaskan penelitian menunjukkan ekspektasi seorang pendidik menentukan kesuksesan orang-orang yang dididik. Dikatakan bahwa ekspektasi terhadap siswa-siswa sangat memengaruhi pencapaian mereka di ruang kelas, dan akhirnya di dalam hidup mereka ke depan. Ekspektasi positif menjadi begitu penting untuk membangkitkan motivasi karena manusia memiliki insting sukses, bahwa manusia ingin selalu sukses dan berjuang untuk memperbesar potensi suksesnya. Seorang pendidik dapat mencapai apa pun bersama para mahasiswa jika ia menetapkan sebuah ekspektasi yang tinggi terhadap perilaku dan performa yang ia sendiri ada/tinggal di dalamnya. 
Pendidik karakter memiliki berbagai macam stigma terhadap para mahasiwa. Ia harus mampu membangun sebuah ekspektasi yang positif terhadap dirinya dan para mahasiswanya. Wong (2009:54) mengingatkan: "Siapa diri Anda dan apa yang Anda lakukan dan katakan sangat memengaruhi anak muda yang akan menjadi warga produktif masa depan."

\section{Proses Pengajaran Yang Memotivasi}

Dalam pembentukkan karakternya, mahasiswa membutuhkan teladan yang mengispirasi. Inspirasi bisa dibagikan lewat berbagai media dan cara dalam pendidikan karakter oleh sang pendidik. Namun, satu hal yang penting dimiliki oleh seorang pendidik yang hendak memberikan inspirasi adalah kemampuan komunikasi. Kemampuan ini dikenal dengan istilah retorika. Iskandar (2010) menjelaskan konsep retorika adalah persuasi. Definisi persuasi adalah (1) tindakan untuk mengubah sikap dan perilaku seseorang dengan menggunakan kata-kata lisan/tertulis; (2) suatu usaha untuk menanamkan opini baru; dan (3) suatu usaha yang dilakukan secara sadar, untuk mengubah sikap, kepercayaan, dan perilaku orang dengan transmisi pesan.

Membentuk karakter memerlukan proses inspirasi. Proses memberi inspirasi adalah sebuah proses persuasi karena di dalamnya ada usaha untuk mengubah sikap, perilaku, opini. Seorang pendidik karakter tidak bisa tidak harus menguasai keterampilan retorika ini. Pada era modern retorika adalah gabungan yang serasi antara pengetahuan, pikiran, kesenian, dan berbicara. Dalam pengertian yang demikian seorang pendidik harus pada tempat yang tepat, pada waktu yang tepat, atas cara yang lebih efektif, mengucapkan kata-kata yang tepat, benar dan mengesankan. Efektivitas retorika ini berarti pendidik harus dapat berbicara jelas, singkat dan efektif, jelas supaya mudah dimengerti, singkat untuk menghemat waktu dan sebagai tanda kepintaran, dan efektif karena apa gunanya berbicara jika tidak membawa efek.

Lebih jauh lagi dijelaskan retorika sebagai seni untuk memengaruhi, menurut Aristoteles, masih membutuhkan tiga hal. Pertama, Anda harus sanggup menunjukkan kepada khalayak bahwa Anda memiliki pengetahuan yang luas, kepribadian yang terpercaya, dan status yang terhormat (ethos). Kedua, Anda harus menyentuh hati khalayak perasaan, emosi, harapan, kebencian, dan kasih sayang mereka (pathos). Para ahli retorika modern lalu menyebutnya imbauan emosional (emotional appeals). Ketiga, Anda meyakinkan khalayak dengan mengajukan bukti atau yang kelihatan sebagai bukti. Di sini Anda mendekati khalayak lewat otaknya (logos). Covey (2005) menjelaskan tentang ethos, pathos, dan logos tersebut dalam konteks memengaruhi melalui Gambar 1 berikut.

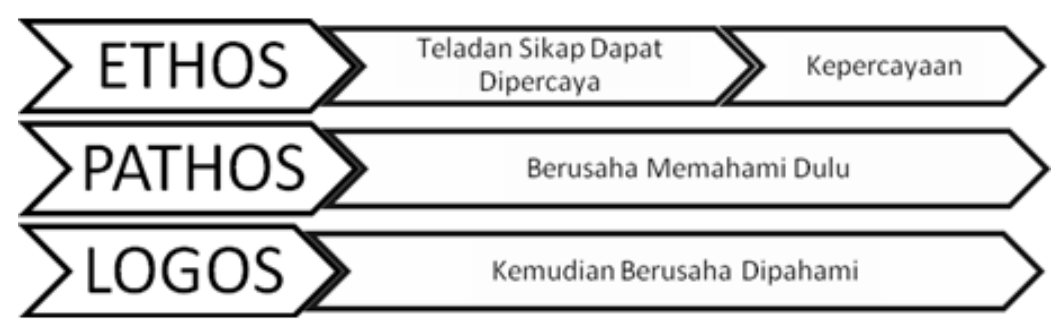

Gambar 1 Falsafah Pengaruh

(Sumber: Covey, 2005:190)

Ethos dalam hal ini berarti kodrat etis pendidik, kredibilitas pribadi, atau besarnya kepercayaan atau keyakinan yang dirasakan oleh orang lain terhadap integritas dan kompetensi pendidik. Ethos diartikan juga sebagai sebuah kecerdasan spiritual (SQ). Pathos merupakan penekanan empati, mengacu kepada emosi atau perasaan. Hal ini berarti bahwa pendidik mau berusaha memahami perasaan orang lain, memahami apa yang menjadi kebutuhannya, bagaimana sudut pandangnya terhadap berbagai hal dan apa yang ia ingin komunikasikan. Ethos yang dalam 
pengertian demikian diartikan sebagai kecerdasan emosional (EQ). Sementara logos menekankan kecerdasan logika, suatu hal yang berkaitan dengan kekuatan dan daya tarik dalam menjelaskan diri dan pemikiran. Ini lebih dikenal dengan kecerdasan intelektual (IQ).

Sebagai pendidik karakter, ethos, pathos, dan logos tersebut harus bekerja secara dinamis sebagai sebuah seni dalam pengajaran untuk membentuk karakter, melalui hidup dan pengajaran yang menginspirasi dan memotivasi. Oleh karena itu dalam proses pembelajaran karakter hubungan antara etos, pathos, dan logos dengan murid ditunjukkan oleh Hendricks (1988) melalui Gambar 2 berikut.

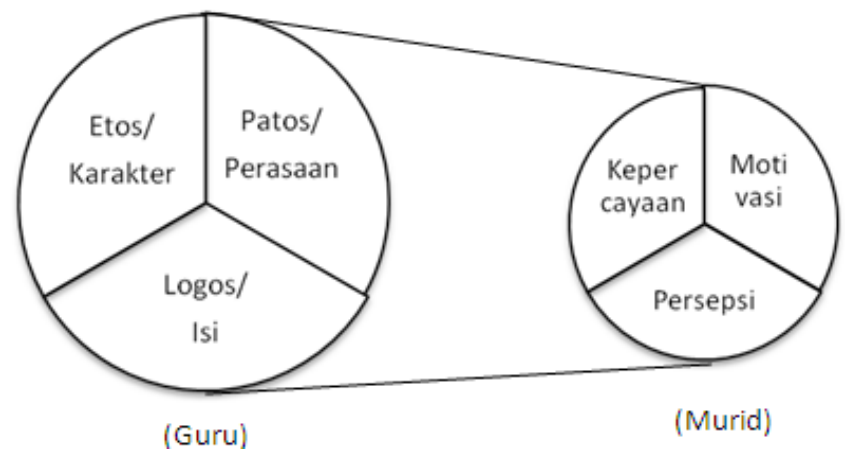

Gambar 2 Etos, Patos, dan Logos dalam Proses Pembelajaran (Sumber: Hendriks, 1988:53)

Diagram menunjukkan bagaimana proses belajar mengajar yang memberi pengaruh bekerja. Logos, patos, dan logos sebagai atribut yang melekat pada sosok pendidik karakter akan menimbulkan kepercayaan, motivasi dan persepsi dalam diri mahasiswa. Motivasi yang muncul dalam diri mahasiswa haruslah bersifat intristik, karena motivasi intristik jauh lebih kuat dan signifikan, namun sebagai pendidik usaha membangkitkan motivasi instristik hanya bisa dilakukan dari luar melalui proses menginspirasi.

Yang dilakukan pendidik untuk menginspirasi dan menghasilkan motivasi intristik dalam diri siswa yakni dengan membuat para siswa menyadari yang menjadi kebutuhan mereka, sehingga mereka mulai bergerak. Hendricks (2009) mengatakan bahwa seorang pengajar harus membantu para siswanya menjadi self-starter karena ketika mahasiswa menjadi self-starter, mereka akan melakukan sesuatu, bukan karena diminta atau dipaksa, melainkan karena mereka yang memilih untuk melakukan itu. Cara terbaik untuk membuat para mahasiswa menjadi self-starter adalah dengan membuat mereka menyadari kebutuhannya. Dalam konteks karakter, para pendidik yang menginspirasi harus membuat para siswa menyadari bahwa mereka membutuhkan karakter yang baik.

Lickona (2012) menekankan bahwa seorang pendidik karakter harus mengajarkan kepada para siswanya alasan pentingnya karakter. Tujuannya untuk menginspirasi para mahasiswa bahwa mereka membutuhkan karakter karena hal itu penting. Kesadaran bahwa karakter itu penting haruslah membawa kepada pengajaran berikutnya bahwa tidak ada seorang pun yang dapat membangun karakter. Artinya, para pendidik karakter harus menyadarkan para mahasiswanya bahwa mereka sesungguhnya bertanggung jawab atas jenis kepribadian yang akan mereka capai. Para pendidik harus menyadarkan para siswanya bahwa pembangunan karakter adalah sebuah pekerjaan dalam hati yang menjadi tanggung jawab mereka pribadi seumur hidup.

\section{Pendidik Kecerdasan Spiritual}

Pendidik karakter yang memotivasi sesungguhnya adalah pengajar yang disebut sebagai kecerdasan spiritual. Mengajarkan karakter sesungguhnya merupakan pengajaran demensi lain dari 
sebuah kecerdasan yaitu dimensi spiritual. Zohar dan Marshall (2007:4) sebagai pencetus istilah spiritual intelligence mendefinisikannya:

"Kecerdasan untuk menghadapi dan memecahkan persoalan makna dan nilai, yaitu kecerdasan untuk menempatkan perilaku dan hidup kita dalam konteks makna yang lebih luas dan kaya, kecerdasan untuk menilai bahwa tindakan atau jalan hidup seseorang lebih bermakna dibandingkan dengan yang lain.”

Dari definisi tersebut dapat dimengerti bahwa kecerdasan spiritual merupakan kecerdasan dalam memberi atau menangkap makna atas sebuah persoalan dengan wawasan yang luas dan mengejahwantahkan makna tersebut dalam suatu tindakan atau jalan hidup yang bernilai. Inilah tujuan yang mau ditanamkan oleh seorang pendidik karakter yang mau menginspirasi dan memotivasi para mahasiswanya, karena ketika seseorang mengerti makna dengan baik, maka hasratnya akan digerakkan oleh makna tersebut. Bahaudin (2007:189-190) menyimpulkan definisi Zohar dengan mengatakan:

\begin{abstract}
"Kecerdasan spiritual adalah kecerdasan yang menyangkut moral (moral intelligence) yang mampu memberikan kita pemahaman yang menyatu dalam diri kita untuk dapat membedakan sesuatu yang benar dengan yang salah atau keliru. Suatu kecerdasan yang mampu membuat kita meningkatkan kebaikan, kebenaran/kejujuran, merasakan keindahan dari hati kita yang dalam dan rasa welas asih terhadap sesama yang merupakan sumber dari simpati dan empati."
\end{abstract}

Definisi Bahaudin ini menjelaskan bahwa ejawantah makna sebagai hasil kecerdasan spiritual diwujudkan dalam jalan hidup yang beretika dan berestetika. Jalan hidup yang beretika dan berestetika tersebut adalah jalan yang hendak dilalui pendidikan karakter. Etika dan estetika yang dihasilkan melalui pengembangan kecerdasan spiritual akan melekat atau menyatu dengan diri karena bersumber dari dalam diri, bukan sekadar tekanan dari hukum, norma, dan faktor luar lainnya. Hal ini pada akhirnya menghasilkan perubahan dari dalam ke luar. Sebagai sebuah kecerdasan yang menghasilkan etika dan estetika, maka kecerdasan spiritual dapat juga diartikan sebagai faktor pelipat ganda kecerdasan atau intelegensi, suatu motif atau penggerak.

Melihat pengertian kecerdasan spiritual dalam pengertian kemampuan memberi makna, maka hal ini dapat dilihat keutamaannya dalam memberikan motivasi dari yang dikatakan Frankl (2004:160), yaitu:

\begin{abstract}
"Upaya manusia mencari makna hidup merupakan motivator utama dalam hidupnya, dan bukan "rasionalisasi sekunder" yang muncul karena dorongan-dorongan naluriahnya. Makna hidup ini merupakan sesuatu yang unik dan khusus, artinya, dia hanya bisa dipenuhi oleh yang bersangkutan; hanya dengan cara itulah dia bisa memiliki arti yang bisa memuaskan keinginan orang tersebut untuk mencari makna hidup."
\end{abstract}

Mencari makna hidup adalah motivator utama bagi manusia untuk menghadapi kehidupan ini dan kecerdasan spiritual adalah ranah kecerdasan yang melakukan tugas mencari makna tersebut. Maka dapat dimengerti bahwa kecerdasan spiritual menampakkan posisinya sebagai kecerdasan dan modal utama bagi manusia dalam menghadapi kehidupan baik secara filosofis juga praktis. Sementara itu, keunikan dan kekhususan dari makna hidup yang hanya bisa dipenuhi oleh pribadi yang bersangkutan memberi keunikan dan kekhususan juga pada kecerdasan spiritual yang di dalamnya kecerdasan spiritual akan memunculkan keunikan dari diri seseorang seiring dengan penemuan akan makna hidup dan peristiwa-peristiwa di dalamnya. Dengan demikian jelas bahwa pendidikan karakter seharusnya ditekankan pada pengembangan kecerdasan spiritual.

Para pendidik karakter harus memulai pendidikan mereka dari spiritualitas dirinya dan para mahasiswanya. Untuk mendapatkan kecerdasan spiritual lebih baik, Zohar dan Marshall (2007:231) mengusulkan 7 langkah sebagai hal yang harus ditanamkan dalam diri para mahasiswa, yaitu: 
menyadari di mana saya sekarang; merasakan dengan kuat bahwa saya ingin berubah; merenungkan apakah pusat saya sendiri dan apakah motiasi saya yang paling dalam; menemukan dan mengatasi rintangan; menggali banyak kemungkinan untuk melangkah maju; menetapkan hati saya pada sebuah jalan; dan tetap menyadari bahwa ada banyak jalan.

Lebih jauh Zohar dan Marshall (2007:201-227) mengusulkan 6 jalan menuju kecerdasan spiritual lebih tinggi yang dihubungkan dengan jenis kepribadian, motivasi, arketipe, tekanan agama, mitos, praktik, dan cakra. Secara umum jalan jalan tersebut adalah (1) Jalan Tugas, berkaitan dengan rasa memiliki, kerja sama, memberikan sumbangan, dan diasuh oleh komunitas; (2) Jalan Pengasuhan, berkaitan dengan kasih sayang, pengasuhan, perlindungan, dan penyuburan; (3) Jalan Pengetahuan bermula dari pemahaman terhadap masalah praktis umum, pencarian filosofis yang paling dalam akan kebenaran, hingga pencarian spiritual akan pengetahuan mengenai Tuhan dan seluruh cara-Nya dan penyatuan terkakhir dengan-Nya melalui pengetahuan; (4) Jalan perubahan pribadi, jalan ini memerlukan integritas personal dan transpersonal memerlukan kepekaan dan keberanian untuk menyelami kedalaman diri sendiri untuk mengukur potensi dan kekuatan kepribadian yang kita miliki; (5) Jalan Persaudaraan, jalan ini mengajarkan makna hidup yang lebih mendalam dengan menyadari bahwa manusia tidak dapat hidup sendirian dan bahwa manusia mempunyai tanggung jawab sosial yang besar. Jalan ini menyakini bahwa individu makin bermakna ketika dapat menjadi orang yang bermakna bagi orang lain, bukan bagi diri sendiri; (6) Jalan Kepemimpinan yang Penuh Pengabdian, seorang pemimpin yang hebat tidak mengabdi kepada suatu apa pun kecuali Tuhan. Yang paling penting bagi seorang pemimpin adalah membangkitkan dalam dirinya dan para pengikutnya semacam kesadaran yang dapat membimbing diri mereka kepada kebenaran.

Para pendidik karakter harus mengerti jalan-jalan pengembangan kecerdasan spiritual ini, dan harus berusaha menerapkannya dalam konteks penugasan kepada para peserta didik. Prinsip-prinsip penugasan yang dapat diberikan kepada mahasiswa dalam rangka pengembangan kecerdasan spiritual sesuai dengan 6 jalan yang ada haruslah disesuaikan dengan motivasi dari keenam jalan pengembangan kecerdasan spiritual tersebut, dengan demikian secara pinsip penugasan tersebut seperti Tabel 1 berikut.

Tabel 1 Jalan Tugas dan Prinsip Penugasan

\begin{tabular}{ll}
\hline \multicolumn{1}{c}{ Jalan : Tugas } & \multicolumn{1}{c}{ Prinsip Penugasan Berdasarkan Motivasi } \\
\hline Tugas: Menjalankan tugas & $\begin{array}{l}\text { Menjadikan mahasiswa suka bergaul, memiliki rasa } \\
\text { memiliki dan keamanan }\end{array}$ \\
\hline Pengasuhan: Mengasuh, melindungi, menyembuhkan & $\begin{array}{l}\text { Menjadikan mahasiswa memiliki kedekatan dan } \\
\text { tanggung jawab sebagai orang tua atau dewasa }\end{array}$ \\
\hline Pengetahuan: Belajar dan mengalami & $\begin{array}{l}\text { Menjadikan mahasiswa lebih memahami, mengetahui } \\
\text { dan menjelajahi pengetahuan yang telah diberikan }\end{array}$ \\
\hline Perubahan pribadi: Pekerjaan imajinatif dan dialog & $\begin{array}{l}\text { Menjadikan mahasiwa lebih kreatif, memiliki cinta diri } \\
\text { dan insting kehidupan yang baik. }\end{array}$ \\
\hline Persaudaraan: Pertukaran peran dan wadah dialog & $\begin{array}{l}\text { Menjadikan mahasiwa lebih berguna atau membangun } \\
\text { sesama dan bangsa }\end{array}$ \\
\hline $\begin{array}{l}\text { Kepemimpinan pengabdian: pengetahuan tentang } \\
\text { diri, meditasi dan guru spiritual }\end{array}$ & $\begin{array}{l}\text { Menjadikan mahasiswa terlatih untuk memimpin, } \\
\text { menggunakan kuasa dan melayani sesama }\end{array}$ \\
\hline
\end{tabular}

Jika penugasan yang diberikan para pendidik karakter menjalankan prinsip-prinsip tersebut, tugas-tugas akan menjadi sarana efektif untuk mengembangkan karakter para mahasiswa.

Dengan melihat keutamaan kecerdasan spiritual, jalan-jalan menempuhnya dan prinsip-prinsip penugasan untuk mengembangkan kecerdasan ini, seorang pendidik karakter yang memotivasi sejatinya adalah seorang pengajar kecerdasan spiritual. Dengan menyentuh kecerdasan spiritual 
mahasiswa, para pendidik membangkitkan kemampuan memberi makna yang pada akhirnya akan membangkitkan daya perubahan dari dalam ke luar.

\section{SIMPULAN}

Pendidikan karakter di perguruan tinggi menghadapi tantangan bahwa karakter para mahasiwa sesungguhnya sudah terbentuk, sehingga dibutuhkan strategi pembelajaran karater yang memiliki daya inspiratif bagi para mahasiwa. Akan tetapi, strategi pembelajaran inspiratif tidak dapat berjalan tanpa adanya sosok pendidik yang juga memotivasi dan menginspirasi. Kunci utama dari strategi pendidikan karakter di perguruan tinggi terletak pada sosok pribadi pendidik yang mampu menginspirasi dan memotivasi. Hal itu disebabkan mahasiswa membutuhkan inspirasi dan motivasi untuk mengevaluasi karakter mereka dan menguasahakan perubahan dari dalam ke luar.

Para pendidik karakter yang memotivasi adalah para pendidik yang menaruh pusat hidup mereka pada panggilan dan pengabdiannya sebagai pendidik, membangun pola relasi "aku-engkau" dengan para mahasiswa, dan memiliki ekspektasi positif pada dirinya dengan para mahasiswanya. Para pendidik karakter yang memotivasi adalah para pendidik yang melibatkan etos, pathos, dan logos dalam proses pembelajarannya untuk membangkitkan kepercayaan, motivasi, dan persepsi yang benar pada diri mahasiswanya. Akhirnya para pendidik karakter yang memotivasi adalah para pengajar kecerdasan spiritual: suatu kecerdasan yang menjadi penggerak utama bagi jenis kecerdasan lainnya.

\section{DAFTAR PUSTAKA}

Asyanti, S. (2012). Pendidikan Karakter di Perguruan Tinggi, Sudah Terlambatkah? Prosiding Seminar Nasional Psikologi Islami, 284-291. Surakarta, 21 April 2012 diunduh 3 Juni 2013 dari http://publikasiilmiah.ums.ac.id/bitstream/handle/ 123456789/ 1780/ D9.\%20SetiaUMS\%20\%28fixed\%29.pdf?sequence=1

Covey, S. R. (1997). 7 Kebiasaan Manusia Yang Sangat Efektif. Jakarta: Binarupa Aksara.

Covey, S. R. (2005). The 8th Habits: Melampaui Efektivitas. Menggapai Keagungan. Jakarta: Gramedia Pustaka Utama.

Dokumen Kebijaksanaan Nasional Pembangunan Karakter Bangsa 2012-2025. Diunduh 4 Juni 2013 dari

http://www.puskurbuk.net/downloads/viewing/Produk_Puskurbuk/2011/Pendidikan_Karakter/ 1_KEBIJAKAN+NAS+PEMB+KARAKTER+BANGSA+2010_2025.zip/

Frankl, V. E. (2004). Man’s Search for Meaning: Mencari Makna Hidup. Bandung: Nuansa.

Hendricks, H. G. (2009). Mengajar untuk Mengubah Hidup. Yogyakarta: Gloria Graffa.

Hendricks, H. G. (1988). The 7 Laws Of The Teacher. Jakarta: World Teach

Iskandar, D. (2010). Retorika sebagai seni bicara. Mentari, 13(2). Diunduh tanggal 3 Juni 2013 dari http://ejournal.unmuha.ac. id/ index.php/mentari/article/view/67

Lickona, T. (2012). Persoalan Karakter. Jakarta: Bumi Aksara. 
Mulyatiningsih, E. (n.d.). Analisis model-model pendidikan karakteruntuk usia anak-anak, remaja dan dewasa. Diunduh 3 Juni 2013 dari http://www.academia.edu/4173395/

PDPERSI. (2012, 11 Mei). SGM Prestasi Center Fasilitasi Pembentukan Karakter Anak. Diakses dari http://www.pdpersi.co.id/content/news.php?mid=5\&catid=23\&nid=800

Snijders, A. (2004). Manusia: Paradoks dan Seruan. Yogyakarta: Kanisius.

Wong, H. K. (2009). The Firsts Days of School. Yogyakarta: Pustaka Pelajar.

Zohar, D., \& Marshall, I. (2007). Kecerdasan Spiritual. Bandung: Mizan. 